OPEN ACCESS

Edited by:

Silvia Fasano,

Università degli Studi della Campania

Luigi Vanvitelli Caserta, Italy

Reviewed by:

Rosaria Meccariello,

Università degli Studi di Napoli

Parthenope, Italy

Juan F. Asturiano,

Universitat Politècnica de

València, Spain

Erika Cottone

Università degli Studi di Torino, Italy

*Correspondence:

Karine Rousseau

karine.rousseau@mnhn.fr

Specialty section:

This article was submitted to

Neuroendocrine Science,

a section of the journal

Frontiers in Endocrinology

Received: 26 September 2017

Accepted: 04 December 2017

Published: 08 January 2018

Citation:

Pasquier J, Lafont A-G, Denis F, Lefranc B, Dubessy C, Moreno-

Herrera A, Vaudry H, Leprince J,

Dufour S and Rousseau K (2018)

Eel Kisspeptins: Identification,

Functional Activity, and Inhibition on

both Pituitary $\mathrm{LH}$ and $\mathrm{GnRH}$

Receptor Expression.

Front. Endocrinol. 8:353.

doi: 10.3389/fendo.2017.00353

\section{Eel Kisspeptins: Identification, Functional Activity, and Inhibition on both Pituitary LH and GnRH Receptor Expression}

\author{
Jérémy Pasquier ${ }^{1}$, Anne-Gaëlle Lafont ${ }^{1}$, Florian Denis ${ }^{1}$, Benjamin Lefranc ${ }^{2}$, \\ Christophe Dubessy ${ }^{2}$, Antonio Moreno-Herrera ${ }^{2,3}$, Hubert Vaudry ${ }^{2}$, Jérôme Leprince ${ }^{2}$, \\ Sylvie Dufour ${ }^{1}$ and Karine Rousseau ${ }^{1 *}$
}

'Muséum National d'Histoire Naturelle, Research Unit BOREA, Biology of Aquatic Organisms and Ecosystems, CNRS 7208, IRD207, UPMC, UCN, UA, Paris, France, ${ }^{2}$ Laboratory of Neuronal and Neuroendocrine Differentiation and Communication, INSERM U1239, Normandy University, Rouen, France, ${ }^{3}$ Department of Cell Biology, Physiology, and Immunology, Maimonides Institute for Biomedical Research of Cordoba (IMIBIC), Reina Sofia University Hospital, University of Córdoba, Córdoba, Spain

The European eel (Anguilla anguilla) presents a blockade of sexual maturation at a prepubertal stage due to a deficient production of gonadotropins. We previously initiated, in the eel, the investigation of the kisspeptin system, one of the major gatekeepers of puberty in mammals, and we predicted the sequence of two Kiss genes. In the present study, we cloned and sequenced Kiss 1 and Kiss2 cDNAs from the eel brain. The tissue distributions of Kiss 1 and Kiss2 transcripts, as investigated by quantitative real-time PCR, showed that both genes are primarily expressed in the eel brain and pituitary. The two 10-residue long sequences characteristic of kisspeptin, eel Kp1(10) and Kp2(10), as well as two longer sequences, predicted as mature peptides, eel Kp1(15) and Kp2(12), were synthesized and functionally analyzed. Using rat Kiss1 receptor-transfected Chinese hamster ovary cells, we found that the four synthesized eel peptides were able to induce $\left[\mathrm{Ca}^{2+}\right]_{\mathrm{i}}$ responses, indicating their ability to bind mammalian KissR-1 and to activate second messenger pathways. In primary culture of eel pituitary cells, all four peptides were able to specifically and dose-dependently inhibit $\operatorname{lh} \beta$ expression, without any effect on $f s h \beta$, confirming our previous data with heterologous kisspeptins. Furthermore, in this eel in vitro system, all four peptides inhibited the expression of the type $2 \mathrm{GnRH}$ receptor (gnrh-r2). Our data revealed a dual inhibitory effect of homologous kisspeptins on both pituitary $\operatorname{lh} \beta$ and gnrh-r2 expression in the European eel.

Keywords: kisspeptins, tissue distribution, functional activity, pituitary cell culture, LH, GnRH receptor, European eel

\section{INTRODUCTION}

The European eel, Anguilla anguilla, exhibits a complex life cycle, with a blockade of sexual maturation at a prepubertal stage (silver stage) as long as its oceanic reproductive migration is prevented. This blockade is due to a deficient production of pituitary gonadotropins (1). The understanding of the mechanisms regulating the gonadotropic axis and controlling eel reproduction is of particular 
interest, considering the drastic decline of wild populations (2) and the current lack of self-sustained aquaculture of this species. Furthermore, as the eel is a representative species of an early group of teleosts (the elopomorpha) (3), deciphering such mechanisms in this species may provide new insights on evolution and ancestral regulations of endocrine systems.

Kisspeptin (Kiss1) gene was first discovered as a metastasis suppressor gene in human melanoma (4). Soon after, an orphan receptor, GPR54, was cloned in the rat (5) and was subsequently identified as the cognate receptor of kisspeptins (Kiss), the natural peptides derived from the product of Kiss1 (6-8). In 2003, a major breakthrough in reproductive endocrinology was achieved, as the GPR54 gene was shown to be essential for the onset of puberty. Mutations in gpr54 caused hypogonadotropic hypogonadism in humans $(9,10)$ and mice $(10,11)$. Later, hypogonadotropic hypogonadism was also observed in Kiss 1 knockout mice (12), while precocious puberty onset occurred in humans with either gpr54-activating mutation leading to prolonged in vitro activation of intracellular signaling pathways in response to kisspeptin (13) or Kiss1 mutations leading to higher in vitro kisspeptin resistance to degradation (14). Since these discoveries, the kisspeptin system has been considered as a major puberty gatekeeper and reproductive regulator, upstream of $\mathrm{GnRH}$ [for reviews see Ref. (15-17)]. Nevertheless, Tang and collaborators (18) recently showed that gametogenesis and reproductive capability are not impaired in zebrafish mutant lines for Kiss, as well as for kisspeptin receptors (KissR), suggesting that the Kiss/ KissR systems may be dispensable for the reproduction of some non-mammalian vertebrates.

The kisspeptin system has been identified in a number of vertebrate species, leading to the discovery of multiple genes encoding kisspeptins (from Kiss1 to Kiss3) as well as multiple genes encoding its receptors (from KissR-1 to KissR-4) [for review see Ref. (19)]. To date, mature amidated kisspeptins have been purified only from human, Xenopus, turtle, and salmon. In human, multiple mature Kiss1 peptides (Kp1), including a mature peptide encompassing 54-aa $[\mathrm{Kp} 1(54)]$ and shorter peptides [Kp1(14) and Kp1(13)], were isolated from placental extracts (6). Mature Kiss peptides, cleaved from the same precursor, share the same C-terminal 10 -aa sequence, which is the minimal sequence required to specifically bind their cognate receptor, as first described for human Kiss1 by Kotani et al. (6). Although Kiss2-like gene has been identified in human, a Kiss2 peptide (Kp2) may not be produced as an endogenous ligand due to the lack of an amidation signal in the precursor polypeptide (20). In Xenopus laevis, a species presenting three Kiss genes (Kiss1, 2, and 3), only Kp2(12) has been isolated by HPLC (21). In the red-eared slider turtle (Trachemys scripta), the mature endogenous Kiss2 peptide is a 12-aa sequence, while in the masu salmon (Oncorhynchus masou), it is a 13-aa sequence (20).

In the eel, three Kiss receptor genes have been characterized, i.e., KissR-1, KissR-2, and KissR-3 (19, 22-24). Their expressions mainly occur in the brain, pituitary, and gonads (19). Using heterologous Kiss peptides [human/lamprey Kp1(10); human Kp1(14); lamprey Kp1(13); and zebrafish Kp1(10), 2(10), 1(15), and $2(15)]$, we previously showed an unexpected and specific in vitro inhibitory effect on luteinizing hormone $(\operatorname{lh} \beta)$ expression by eel pituitary cells in primary culture (22). Three GnRH receptors were identified in the eel, two of type I (Gnrh-r1a and 1b) and one of type II (Gnrh-r2); all were shown to be expressed in the brain, pituitary, and gonads (25).

In the present study, we report the cloning of two eel Kiss transcripts (Kiss 1 and Kiss2), corresponding to the two previously defined ORFs (23). Using a specific quantitative real-time PCR (qPCR) approach, we investigated their distributions in various eel tissues. We synthesized the two minimal 10-aa peptides, eel $\mathrm{Kp} 1(10)$ and $\mathrm{Kp} 2(10)$, as well as the predicted mature peptides, eel Kp1(15) and Kp2(12). We tested all four peptides on rat KissR1 -transfected Chinese hamster ovary $(\mathrm{CHO}-\mathrm{K} 1)$ cells. We also studied their biological effects on the expression of gonadotropins ( $l h \beta$; follicle-stimulating hormone, $f s h \beta$ ) and gonadotropinreleasing hormone receptors $(g n r h-r)$ by eel pituitary cells in primary culture.

\section{MATERIALS AND METHODS}

\section{Animals}

European female eels were at the prepubertal "silver" stage, which corresponds to the last continental phase of the eel life cycle, preceding the oceanic reproductive migration. Eels were purchased from Gebr. Dil import-export BV (Akersloot, The Netherlands) and transferred to MNHN, France.

Animals were anesthetized by cold and then killed by decapitation under the supervision of authorized person (Karine Rousseau; No. R-75UPMC-F1-08) according to the protocol approved by Cuvier Ethic Committed (No. 68-027).

\section{Cloning and Sequencing of European Eel Kiss1 and Kiss2 cDNAs}

Total RNA from eel brain (pooled di-/mesencephalon) was extracted using Trizol reagent and reverse transcribed as previously described (22).

Predicted genomic sequences of eel Kiss 1 and $\operatorname{Kiss} 2(23,26)$ were used to design specific Kiss 1 and Kiss 2 primers, respectively (Table 1). Using the Advantage 2 PCR Kit (Clontech Laboratories Inc., PaloAlto, CA, USA), RACE PCRs with 5'-cDNA or 3'CDNA as templates were performed as follows: an initial step of polymerase activation for $3 \mathrm{~min}$ at $94^{\circ} \mathrm{C}$; then 10 cycles of $30 \mathrm{~s}$ at $94^{\circ} \mathrm{C}$ for denaturing, $30 \mathrm{~s}$ at $70^{\circ} \mathrm{C}$ for annealing, $90 \mathrm{~s}$ at $72^{\circ} \mathrm{C}$ for primer extension; and then 25 cycles of $30 \mathrm{~s}$ at $94^{\circ} \mathrm{C}$ for denaturing, $30 \mathrm{~s}$ at $68^{\circ} \mathrm{C}$ for annealing, $90 \mathrm{~s}$ at $72^{\circ} \mathrm{C}$ for primer extension, and a single final extension step of $5 \mathrm{~min}$ at $72^{\circ} \mathrm{C}$. PCR products of appropriate estimated size were sequenced at GATC Biotech Ltd. (Konstanz, Germany).

The signal peptides of the Kiss precursors were predicted using SignalP tool (28). Cleavage and amidation sites, as well as mature peptides, were predicted from the Kiss precursor using NeuroPred tool (29).

\section{Synthesis of Eel Kp1 and 2 Peptides}

European eel Kp1(10), Kp2(10), Kp1(15), and Kp2(12) (Table 2) were synthesized $(0.1-\mathrm{mmol}$ scale) by the solid-phase 
TABLE 1 | Primers used in the $3^{\prime}$ - and 5'-RACE PCR and quantitative real-time PCR (qPCR) amplifications.

\begin{tabular}{|c|c|c|}
\hline Primers & $5^{\prime}-3^{\prime}$ sequence $(\mathrm{bp})$ & \\
\hline \multicolumn{3}{|c|}{ Primers for $3^{\prime}$-RACE PCR } \\
\hline Kiss1-F & CGCCACAAGCGGCCAAGAAG & \\
\hline Kiss2-F & AGGGCCACATTTCCTGCCGACT & \\
\hline \multicolumn{3}{|c|}{ Primers for 5'-RACE PCR } \\
\hline Kiss1-R & CCCGCTTCTTGGCCGCTTGT & \\
\hline Kiss2-R & CCGAACGGATTGCGGTTGAATITG & \\
\hline \multicolumn{3}{|c|}{ Primers for qPCR } \\
\hline Kiss1-F & GGTCTCTTAGGTACACCCCGT & This study \\
\hline Kiss1-R & ACAGCTCCTCGCTCATITG & \\
\hline Kiss2-F & ACGGACGACTCAGGTTCTCT & This study \\
\hline Kiss2-R & GCCCTCGATTTCACTGTCTT & \\
\hline actin-F & AGTATITGCGCTCGGGTG & Aroua et al. (27) \\
\hline actin- $\mathrm{R}$ & CAGCCTTCCTTCCTGGGT & \\
\hline $\ln \beta-\mathrm{F}$ & TCACCTCCTTGTTTCTGCTG & Aroua et al. (27) \\
\hline $\operatorname{lh} \beta-\mathrm{R}$ & TAGCTTGGGTCCTTGGTGATG & \\
\hline$f \operatorname{sh} \beta-\mathrm{F}$ & TCTCGCCAACATCTCCATC & Aroua et al. (27) \\
\hline $\operatorname{fsh} \beta-\mathrm{R}$ & AGAATCCTGGGTGAAGCACA & \\
\hline gnrh-r1a-F & TGGTCATGAGTTGCTGCTACA & Penaranda et al. (25) \\
\hline gnrh-r1a-R & AGACACCCCTCTCCGTCTIT & \\
\hline gnrh-r1b-F & TCGTCACGCTCTACGTTGTC & Penaranda et al. (25) \\
\hline gnrh-r1b-R & AGGCAGGACTCTCCACCTाT & \\
\hline gnrh-r2-F & TCACСТTСТССТGССТСТTС & Penaranda et al. (25) \\
\hline gnrh-r2-R & TTGGAAGATGCCTTCCCTाT & \\
\hline
\end{tabular}

TABLE 2 | Sequences of predicted eel kisspeptins.

\begin{tabular}{lclc}
\hline Peptide & Symbol & Sequence & Length (aa) \\
\hline Eel 1 kisspeptin-10 & Kp1(10) & YNWNSFGLRY-NH2 & 10 \\
Eel 1 kisspeptin-15 & Kp1(15) & ENFSSYNWNSFGLRY-NH2 & 15 \\
Eel 2 kisspeptin-10 & Kp2(10) & FNRNPFGLRF-NH2 & 10 \\
Eel 2 kisspeptin-12 & Kp2(12) & SKFNRNPFGLRF-NH2 & 12 \\
\hline
\end{tabular}

methodology on a Rink amide 4-methylbenzhydrylamine resin (Biochem, Meudon, France) using a 433A peptide synthesizer (Applied Biosystems, Courtaboeuf, France) and the standard procedure, as previously described (30). The synthetic peptides were purified by reversed-phase (RP) HPLC on a $2.2 \mathrm{~cm} \times 25 \mathrm{~cm}$ Vydac 218TP1022 $\mathrm{C}_{18}$ column (Alltech, Templemars, France), using a linear gradient (20-40\% over $60 \mathrm{~min}$ ) of acetonitrile/TFA $(99.9: 0.1, \mathrm{v} / \mathrm{v})$ in water, at a flow rate of $10 \mathrm{ml} / \mathrm{min}$. Analytical RP-HPLC, performed on a $0.46 \mathrm{~cm} \times 25 \mathrm{~cm}$ Vydac $218 \mathrm{TP} 54 \mathrm{C}_{18}$ column, showed that the purity of the peptide was greater than $99 \%$. The molecular mass of the peptide was verified by mass spectrometry on a MALDI-TOF Voyager DE-PRO instrument (Applied Biosystems).

\section{Functional Activity of Eel Kp1 and Kp2 Peptides in Rat KissR-1-Transfected CHO-K1 Cells}

$\mathrm{CHO}-\mathrm{K} 1$ cells were cultured to semiconfluence in 12 -well plates using Ham's F12 medium supplemented with 10\% fetal bovine serum and $1 \%$ antibiotic-antimycotic solution. Cells were transfected with different quantities of the recombinant plasmid, ranging from 3 to $5 \mu \mathrm{g}$, using Lipofectamine 2000 (Invitrogen,
TABLE 3 | Functional parameters of the response of KissR-1 CHO-K1 cells to treatment with eel kisspeptins as measured using FlexStation technology.

\begin{tabular}{lcc}
\hline Peptide & $\boldsymbol{E}_{\max } \pm$ SEM (\%) & EC $_{50} \pm$ SEM (nM) \\
\hline Eel Kp1(10) & $235.5 \pm 8.4$ & $8.5 \pm 4.5$ \\
Eel Kp1(15) & $276.6 \pm 5.3$ & $11.8 \pm 2.0$ \\
Eel Kp2(10) & $259.9 \pm 9.5$ & $56.6 \pm 27.7$ \\
Eel Kp2(12) & $255.9 \pm 6.7$ & $134.7 \pm 18.9$ \\
\hline
\end{tabular}

Cergy Pontoise, France) as previously described (30). Twentyfour hours after transfection, media were replaced by fresh F12

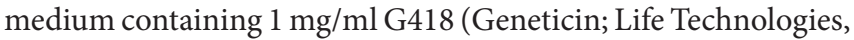
Inc.). One week later, surviving cells were detached, diluted, and plated on 96-well plates at 0.7 cells/well. Monoclonal cell lines expressing rat KissR-1 (CHO-K1-rKissR-1) were followed daily by contrast phase microscopy. Seven independent monoclonal stable cell lines were obtained after a 3 -week period of selection. By using qPCR, two cell lines were selected based on their expression levels being closest to physiological levels among all cell lines. Of these, one cell line was definitely selected based on its best performance in showing clear $\mathrm{Ca}^{2+}$-mobilizing responses to treatment with rat $\mathrm{Kp} 1(10)$.

To compare the KissR-1 agonistic activities of eel Kp1(10), $\mathrm{Kp} 2(10)$, Kp1(15), and $\mathrm{Kp} 2(12)$, the level of $\left[\mathrm{Ca}^{2+}\right]_{\mathrm{i}}$ after stimulation of CHO-K1 cells stably expressing KissR-1 by these peptides was monitored by spectrofluorometry as previously described $(30,31)$ with slight modifications. Briefly, after $24 \mathrm{~h}$ in culture, cells were incubated for $1 \mathrm{~h}$ in a humidified incubator $\left(37^{\circ} \mathrm{C}, 5 \% \mathrm{CO}_{2}\right)$ with $2 \mu \mathrm{M}$ Fluo- 4 acetoxymethyl ester (AM) calcium dye (Life Technologies, Saint Aubin, France) in Hank's Buffer Saline Solution (HBSS; Life Technologies) buffered with $5 \mathrm{mM}$ HEPES and supplemented with $2.5 \mathrm{mM}$ probenecid (Sigma-Aldrich, Saint-Quentin Fallavier, France). Cells were washed twice with HBSS/HEPES/probenecid to remove Fluo- $4 \mathrm{AM}$ from the incubation medium and incubated in $150 \mu \mathrm{l}$ of the same medium at $37^{\circ} \mathrm{C}$ for $15 \mathrm{~min}$. Fluorescence was recorded using a Flexstation 3 fluorescence plate reader system (Molecular Devices, Saint-Grégoire, France) during $180 \mathrm{~s}$ with an excitation wavelength of $480 \mathrm{~nm}$, an emission wavelength of $525 \mathrm{~nm}$, and a cutoff filter of $515 \mathrm{~nm}$. After $15 \mathrm{~s}$ recording in basal conditions, $50 \mu \mathrm{l}$ of graded concentration $\left(10^{-12}\right.$ to $\left.10^{-6} \mathrm{M}\right)$ of different peptides (four-fold final concentration) was added to the incubation medium with the built-in eight-channel pipettor at a rate of $62 \mu \mathrm{l} / \mathrm{s}$ to assess their agonistic activity. After subtraction of mean fluorescence background from control wells without Fluo-4 AM, baseline was normalized to $100 \%$, and fluorescence peak values were determined for each concentration of peptide. Potency $\left(E_{50}\right)$ and efficacy $\left(E_{\max }\right)$ (Table 3 ) were determined with the Prism 6.0 software (GraphPad Software In., La Jolla, CA, USA) using a four-parameter logistic equation to fit peak fluorescence data.

\section{Tissue Distribution of Kiss Transcripts in the European Eel}

Various tissues were individually collected from eight freshwater female silver European eels to investigate the distribution of Kiss 1 and Kiss 2 expressions using qPCR. The following tissues were 
sampled, stored in RNAlater (Ambion-Inc., Austin, TX, USA), and kept frozen at $-20^{\circ} \mathrm{C}$ until RNA extraction: brain, pituitary, eye, liver, kidney, intestine, spleen, muscle, adipose tissue, and ovary. The brain was dissected into six parts olfactory bulb, telencephalon, mesencephalon, diencephalon, cerebellum, and medulla oblongata. In addition, testes from eight freshwater male silver European eels were also collected.

\section{Primary Culture of Eel Pituitary Cells and In Vitro Treatments Dispersion and Culture}

Dispersion and primary culture of pituitary cells from 30 freshwater female silver eels were performed using an enzymatic and mechanical procedure as described by Ref. (33) and as previously used for the test of heterologous kisspeptins (22). Cultures were performed in serum-free culture medium (Medium 199 with Earle's salt, sodium bicarbonate, $100 \mathrm{U} / \mathrm{ml}$ penicillin, $100 \mu \mathrm{g} / \mathrm{ml}$ streptomycin, and $250 \mathrm{ng} / \mathrm{ml}$ fungizone) (Gibco, Thermo Fisher Scientific, Villebon sur Yvette, France) at $18^{\circ} \mathrm{C}$ under $3 \% \mathrm{CO}_{2}$ and saturated humidity.

\section{In Vitro Treatments}

Hormonal treatments were started $24 \mathrm{~h}$ after the beginning of culture to allow cell attachment (Day 0). Replicates of five wells for control and each treated group were used. Eel Kp1(10), Kp1(15), Kp2(10), and Kp2(12) were tested (see Table 2). Kisspeptin stock solutions $\left(10^{-4} \mathrm{M}\right)$ were prepared in ultrapure water and stored at $-20^{\circ} \mathrm{C}$. Stock solutions were diluted in culture medium just before addition to the culture wells. Culture medium was changed and kisspeptins were added to the cells on Day 0, Day 3, and Day 7. Control wells were treated with similar dilutions of ultrapure water. Cultures were stopped on Day 10, according to Ref. (22). The effects of treatments $\left(10^{-7}\right.$ to $10^{-11} \mathrm{M}$ ) were tested in at least three independent experiments performed on different cell preparations from different batches of fish.

\section{RNA Extraction and cDNA Synthesis}

Tissue samples were individually homogenized by sonication in Trizol, and total RNAs were extracted according to the manufacturer's instructions (Invitrogen). Following extraction, samples were treated with DNase I (Roche, Meylan, France), and the first strand of cDNA was synthesized from $400 \mathrm{ng}$ of total RNA using Superscript III reverse transcriptase (Invitrogen) and random hexamer primers. The reaction was performed according to the following thermal conditions with an initial step at $25^{\circ} \mathrm{C}$ for $10 \mathrm{~min}$ followed by incubation at $50^{\circ} \mathrm{C}$ for $60 \mathrm{~min}$ and $70^{\circ} \mathrm{C}$ for $15 \mathrm{~min}$. The samples obtained were stored at $-20^{\circ} \mathrm{C}$ until qPCR. The extracted RNAs were the same as in Ref. (19).

For cell cultures, total RNA was directly extracted in wells using the Cell-to-cDNA II Kit (Ambion, Thermo Fisher Scientific) according to the manufacturer's recommendations. Cells were washed with sterile phosphate buffer (Gibco) and lysed with Cell Lysis II Buffer $(80 \mu \mathrm{l} /$ well $)$. The lysates were digested with
RNase-free DNase I (Roche). Four microliters of RNA solution of each sample was then reverse transcribed with a SuperScript III First Strand cDNA Synthesis Kit (Invitrogen). The samples obtained were stored at $-20^{\circ} \mathrm{C}$ until qPCR.

\section{Quantitative Real-time PCR}

Eel Kiss1- and Kiss2-specific primers for qPCR (Table 1) were designed based on the European eel cDNA sequences cloned in this study and using Primer3 Software (Whitehead Institute/ Massachusetts Institute of Technology, Boston, MA, USA). To optimize the assays, different annealing temperatures were tested according to the melting temperature $\left(T_{\mathrm{m}}\right)$ of primers. To assess their specificity, amplification products were sequenced at GATC Biotech Ltd.

The qPCR primers for European eel $\beta$-actin, $\operatorname{lh} \beta, f s h \beta$, gnrh$r 1 a, g n r h-r 1 b$, and gnrh- $r 2$ were previously designed $(25,27)$ (Table 1). $\beta$-actin was used as reference gene. All primers were purchased from Eurofins (Ebersberg, Germany).

Quantitative assays of eel Kiss1, Kiss2, $\operatorname{lh} \beta, f \operatorname{sh} \beta$, gnrh-r1a, gnrh-r1b, gnrh-r2, and $\beta$-actin mRNAs were performed using the LightCycler ${ }^{\circledR}$ System (Roche) with SYBR Green I sequenceunspecific detection as previously described $(19,22,23)$. The qPCRs were prepared with $4 \mu$ of diluted cDNA template, $2 \mu \mathrm{l}$ of PCR grade water, $2 \mu \mathrm{l}$ of SYBR Green master mix, and $1 \mu \mathrm{l}$ of each forward and reverse primers $(0.5 \mathrm{pmol}$ each at final concentration). The qPCRs were performed as follows: an initial step of polymerase activation for $10 \mathrm{~min}$ at $95^{\circ} \mathrm{C}$; then 41 cycles of $15 \mathrm{~s}$ at $95^{\circ} \mathrm{C}$ for denaturing, $5 \mathrm{~s}$ at $60^{\circ} \mathrm{C}$ for annealing, $10 \mathrm{~s}$ at $72^{\circ} \mathrm{C}$ for primer extension $(\beta$-actin, $\operatorname{lh} \beta, f s h \beta)$ or 51 cycles of $15 \mathrm{~s}$ at $95^{\circ} \mathrm{C}$ for denaturing, $5 \mathrm{~s}$ at $61^{\circ} \mathrm{C}$ for annealing, $5 \mathrm{~s}$ at $72^{\circ} \mathrm{C}$ for primer extension, $5 \mathrm{~s}$ at $83^{\circ} \mathrm{C}$ to avoid measurement of non-specific annealing (Kiss1, Kiss2) or 42 cycles of $10 \mathrm{~s}$ at $95^{\circ} \mathrm{C}$ for denaturing, $7 \mathrm{~s}$ at $61^{\circ} \mathrm{C}$ for annealing, $4 \mathrm{~s}$ at $72^{\circ} \mathrm{C}$ for primer extension ( $\left.g n r h-r 2\right)$, or 42 cycles of $10 \mathrm{~s}$ at $95^{\circ} \mathrm{C}$ for denaturing, $10 \mathrm{~s}$ at $60^{\circ} \mathrm{C}$ for annealing, $7 \mathrm{~s}$ at $72^{\circ} \mathrm{C}$ for primer extension (gnrh-rla, gnrh-r $\left.1 b\right)$; and a single final extension step of $5 \mathrm{~min}$ at $72^{\circ} \mathrm{C}$. Each qPCR run contained a non-template control (cDNA was substituted by water) for each primer pair. The efficiency of primers and the specificity of reaction were assessed as previously described (19). Serial dilutions of cDNA pool of brain and pituitary tissues were run in duplicate and used as a common standard curve and also included in each run as a calibrator.

Quantitative real-time PCR efficiencies for Kiss1 and Kiss2 primers (calculated by standard dilution curves) were as follows: Kiss 1 89.84\% and Kiss2 88.05\%. Assay included a melting curve analysis for which all samples displayed a specific single peak.

Normalization of data was performed using total RNA content for the tissue distribution samples, and using $\beta$-actin mRNA level for the cell culture samples.

\section{Statistical Analysis}

Results are given as mean \pm SEM. Non-parametric tests were performed. Mean values were compared by one-way ANOVA Tukey's multiple comparison test using Instat (GraphPad Software Inc., San Diego, CA, USA). 


\section{RESULTS}

\section{Identification of European Eel Kisspeptins Cloning of European Eel Kiss1 and Kiss2 cDNAs}

Using European eel-specific Kiss1 primers designed on eel Kiss1predicted genomic sequence $(23,26)$, RACE PCRs, performed on brain cDNAs, led to the cloning of a partial Kiss 1 transcript sequence (EMBL: LT962662) encompassing a partial coding sequence (CDS) of $314 \mathrm{bp}$ and partial $3^{\prime}$-UTRs of $30 \mathrm{bp}$. Once translated, the cloned Kiss1 CDS gave a partial 103-aa kisspeptin precursor exhibiting a 10-aa sequence (YNWNSFGLRY) characteristic of the kisspeptin family (Figure 1A).

Using European eel-specific Kiss2 primers designed on eel Kiss2predicted genomic sequence $(23,26)$, RACE PCRs, performed on brain cDNAs, led to the isolation of the complete Kiss 2 transcript sequence (EMBL: LT844561). The sequence encompassed 5' - and 3'-UTR of 114 and $495 \mathrm{bp}$, respectively, and a CDS of $402 \mathrm{bp}$. Once translated, the cloned Kiss2 CDS gives a 134-aa kisspeptin precursor exhibiting a 10-aa sequence (FNRNPFGLRF) characteristic of the kisspeptin family (Figure 1B).

BLASTN analyses performed on the European eel draft genome, using the present eel Kiss 1 and Kiss 2 cloned sequences as queries, revealed that each transcript is encoded by two exons. Concerning Kiss2, the first exon encoded a 21-aa signal peptide. Both Kiss 1 and Kiss2 exons-2 encoded the Kiss1 and Kiss2 mature peptides, respectively, including the characteristic 10-aa sequences of the kisspeptin family.

\section{Prediction of European Eel Mature Kiss Peptides}

The identification of the potential $\mathrm{N}$-terminal and C-terminal cleavage sites of each precursor led to the prediction of two N-terminal extended putative mature peptides: Kp1(15) from Kiss1 and Kp2(12) from Kiss2 (Figure 1). Eel Kiss1 presented a conserved dibasic site (KR), 5 amino acids upstream the decapeptide, showing that a mature peptide of 15 amino acids [Kp1(15)] may be produced. Eel Kiss 2 possessed a single basic amino acid (R) at position 13, indicating that the Kiss 2 cDNA encoded a putative peptide with 12 amino acids [Kp2(12)]. A 31-aa mature peptide for Kiss 1 and a 51-aa mature peptide for Kiss 2 could also be predicted (Figure 1A).

The sequence of eel $\mathrm{Kp1}(10)$ is identical to rat Kp1(10). In contrast, $\mathrm{Kp} 2(10)$ is a newly identified sequence, which presented at its third position an arginine (R) that possessed different physicochemical properties from amino acids commonly found at this position. Kp1 and Kp2 sequences were followed at their $\mathrm{C}$-terminal side by a proteolytic cleavage and/or an $\alpha$-amidation motif, i.e., GK motif for Kiss 1 and GKR motif for Kiss 2 precursors, respectively (Figure 1B).

\section{Tissue Distribution of European Eel Kiss1 and Kiss2 mRNAs}

Specific qPCR protocols were developed for each eel Kiss and applied to the analysis of their respective tissue distribution (Figure 2).

\section{Kiss1 mRNA Distribution}

Kiss $1 \mathrm{mRNAs}$ were mainly expressed in the mesencephalon part of the brain. Its expression was lower in the diencephalon, close to the limit of detection in the telencephalon and cerebellum and under detection threshold in the olfactory bulb and medulla oblongata. Kiss 1 expression was abundant in the pituitary. In peripheral tissues, low Kiss 1 mRNA levels were measured in the eye and the testis. Its expression was at the limit of detection in muscle and under the detection threshold in the other investigated tissues (liver, kidney, intestine, spleen, adipose tissue, and ovary) (Figure 2B).

\section{Kiss2 mRNA Distribution}

Kiss 2 mRNAs were mainly expressed in the diencephalon. Kiss 2 expression was lower in the mesencephalon and in the medulla oblongata, and under the detection threshold in the olfactory bulb, telencephalon, and cerebellum. Kiss 2 expression was also observed in the pituitary. In peripheral tissues, a low expression of Kiss 2 was detected in the testis. The expression level was under the limit of detection in the other tissues (eye, liver, kidney, intestine, spleen, adipose tissue, and ovary) (Figure 2C).

\section{Functional Properties of Eel Kiss Peptides}

The two 10-aa peptides, Kp1(10) and Kp2(10), and the two predicted mature peptides, Kp1(15) and Kp2(12), were synthesized for functional assays (Table 2). The functional activity of the four synthesized eel kisspeptins was assessed on the kinetics of $\left[\mathrm{Ca}^{2+}\right]_{i}$ in CHO-K1 cells stably transfected with the rat KissR-1, by using a multimode FlexStation III system. All four kisspeptins were able to activate the rat Kiss1R, i.e., to trigger intracellular pathways leading to $\left[\mathrm{Ca}^{2+}\right]_{i}$ increase. As shown in Figure 3 and Table 3, eel/rat Kp1(10) and the other eel Kiss peptides, Kp1(15), Kp2(10), and $\mathrm{Kp} 2(12)$, displayed the following $\mathrm{EC}_{50}$ values: $8.5 \pm 4.5$, $11.8 \pm 2.0,56.6 \pm 27.7$, and $134.7 \pm 18.9 \mathrm{nM}$, respectively.

\section{Effects of Eel Kiss Peptides on Primary Culture of Eel Pituitary Cells}

We previously demonstrated that heterologous kisspeptins [human/lamprey Kp1(10); human Kp1(14); lamprey Kp1(13); zebrafish Kp1(10), Kp2(10), Kp1(15), and Kp2(15)] can inhibit $\operatorname{lh} \beta$ expression by eel pituitary cells in primary culture, with no effect on $f \operatorname{sh} \beta$ (22). In the present study, we tested the effects of concentrations ranging from $10^{-11}$ to $10^{-7} \mathrm{M}$ of the homologous eel kisspeptins over 10 days in the same culture system.

\section{Effects of Eel Kiss Peptides on Gonadotropin Expression}

All four eel synthesized kisspeptins [Kp1(10), Kp1(15), Kp2(10), and $\mathrm{Kp} 2(12)]$ significantly inhibited $\operatorname{lh} \beta$ expression at $10^{-7} \mathrm{M}$ $[\times 0.63$ with $\mathrm{Kp} 1(10), P<0.001 ; \times 0.59$ with $\mathrm{Kp} 2(10), P<0.001 ; \times$ 0.60 with $\mathrm{Kp} 1(15), P<0.001 ; \times 0.62$ with $\mathrm{Kp} 2(12), P<0.001]$ (Figure 4A). Inhibition by Kp2(10) and Kp2(12) was also significant at $10^{-9} \mathrm{M}(\times 0.71, P<0.05$ and $\times 0.70, P<0.01$, respectively $)$. In contrast, the eel Kiss peptides had no significant effect on $f \operatorname{sh} \beta$ expression at any dose tested (Figure 4B).

\section{Effects of Eel Kiss Peptides on GnRH Receptor Expression}

Among the three eel GnRH receptors, gnrh-r2 was the only one with detectable specific expression in both control and treated 
A

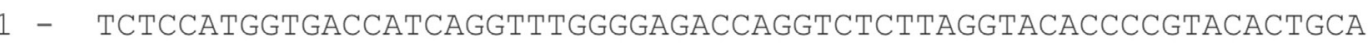

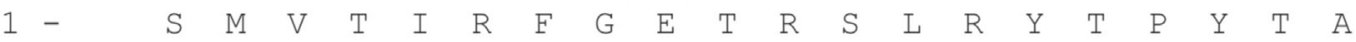

63 - GATGAAGACCCAGAGATtGCAGCCATGCGGGTCCTGAGGCAAATGAGCGAGGAGCTGTCGACC

21 - $\begin{array}{lllllllllllllllllllll} & \mathrm{E} & \mathrm{D} & \mathrm{P} & \mathrm{E} & \mathrm{I} & \mathrm{A} & \mathrm{A} & \mathrm{M} & \mathrm{R} & \mathrm{V} & \mathrm{L} & \mathrm{R} & \mathrm{Q} & \mathrm{M} & \mathrm{S} & \mathrm{E} & \mathrm{E} & \mathrm{L} & \mathrm{S} & \mathrm{T}\end{array}$

126 - GAGGCCCCGCCCTACCCGCACCGCCCCGCCCACTGGCCCACCGCACTGGCCAATCCACTGCCG

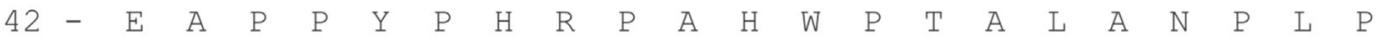

189 - GGAGGGgCCGGCCTTCCCAGGAGGTCGTGGTGGTGGTACCCCGAGGTGCCGCCACAAGCGGCC

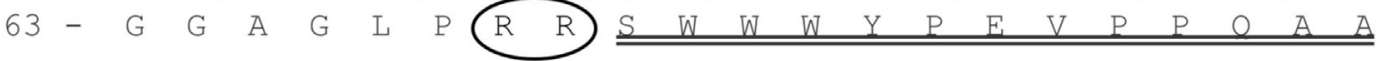

252 - AAgAAGCGGGAAAACTTCTCCTCCTACAACTGGAACTCTTTCGGTTTACGTTATGGGAAATGA

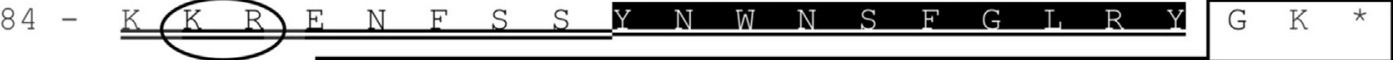

315 - CTCGGAAGCGAGCTGTCAATCACTCTAACC

B

1 - AggCAACTCATCTTCAgtATCACAgCtAACCAgAAAgGgtTTGTAATACGAAgCtgGgCtATA

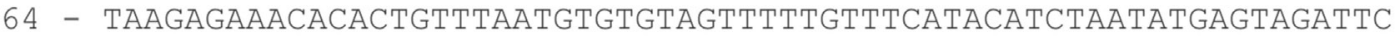

$1-$

M $-\stackrel{S}{R}-\frac{F}{--}$

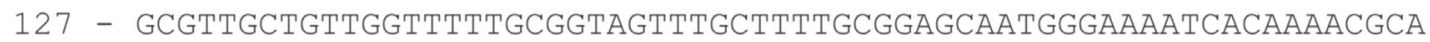

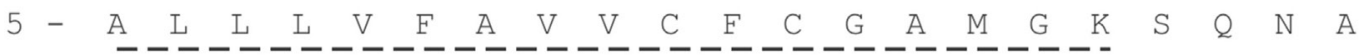

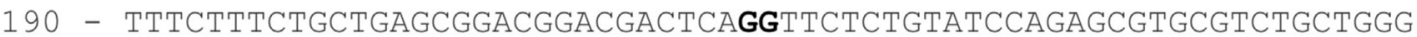

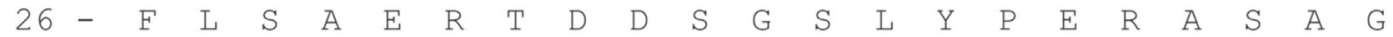

253 - GTCTGGGACCECTCTAAAGTACTGAgAGAAGTCACGGGTCCGAATTATTCAGACGAAGCAGAT

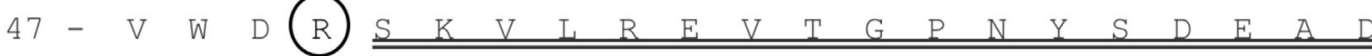

316 - ctCTgCTTCTTCCTGAAAGACAgTGAAATCGAGGGCCACATTTCCTGCCGACTCCGATACTCT

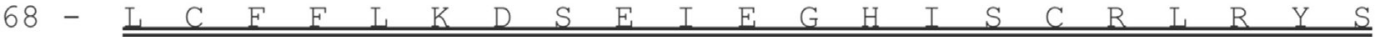

379 - CGAAGCAAATTCAACCGCAATCCGTTCGGTCTCCGTTTTGGAAAACGTGAGTGGAGTTACCTT

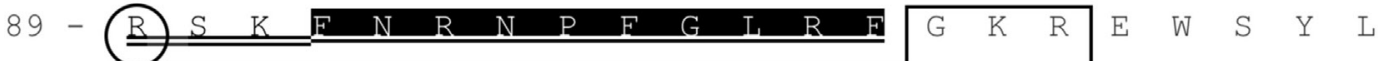

442 - CCCAAGAGCAAAACTGCAAAACCCGGGACAAGCAAGCTTCTCCCCTATCTACTGTACATCCAA

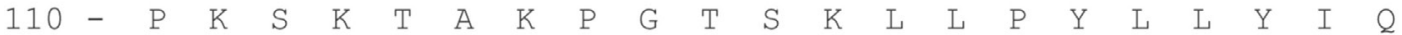

505 - GAGCGGAAAGCCTGACTGGACAAGCAGTCCTCATCCATGGGTTTTTGAAATTTTATGATAACT

131 - E R K A *

568 - GAgATATGTTCATTCCAATTTCCATATTACGCCACATGTTAAACATTGTCATTGTGTGTGTTA

631 - ATtAAAACGTCCTGTATTCTGTTAAACACATATGTTGTCCAGTGAAATGGTCAGATGACCACC

694 - TTTAAGTAGACGGATTTGCTTTTTAACAGGATATTTTATGTGAAGACATTATTAATTTAATCA

757 - ATCAAGCCTACGTTAATGTTAGGAAAATATTTATTTGTTTGCATTATATTCGCGTAGCCAGTT

820 - TTATTGTGCCGGTGGCAACAATGTCCATTGTGAGTGCTTTTCGCCCATGCCTCTATTATATTT

883 - GAGCAAATAGAATTAGTGTCACCAGAAACCACAAGGGCGCGAGGAGTACAAGTTTTCTTTTCA

946 - GTACTTTTCATAATGGAAATGAgCTGTGTATCTTGAAACGATCAATGAGGTGGTTTAATCAGA

1009 - AATAAAAGCGGATAAA

FIGURE 1 | Cloning of eel partial Kiss1 mRNA (A) and complete Kiss2 mRNA (B). Nucleotides (upper line) are numbered from 5' to 3'. The exon-intron junctions are indicated by two nucleotides in bold. The deduced amino acids (bottom line) are numbered beginning with the first methionine residue (M) in the ORF (for Kiss2) or with the first codon of the known sequence (for Kiss1 partial mRNA). The asterisk $\left(^{\star}\right)$ indicates the stop codon, and signal peptide sequence is underlined by a dashed line. Kp1(10) and Kp2(10) are shaded in black. Kp1(15) and Kp2(12) are underlined by a bold line. Kp1(31) and Kp2(51) are underlined by a double line. $\mathrm{C}$-Terminal proteolytic $\alpha$-amidation sites are boxed in a square and predicted $\mathrm{N}$-terminal cleavage sites are circled. 


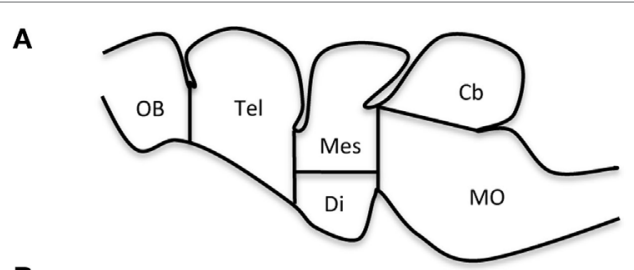

B
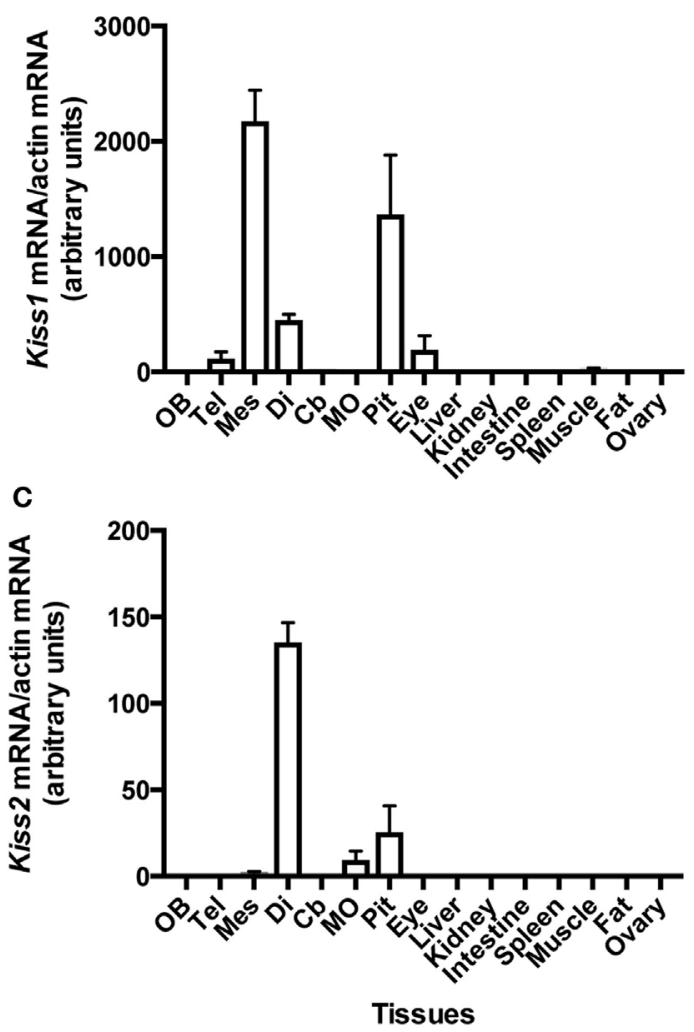

FIGURE 2 | Schematic representation of eel brain with dissection cut sites indicated adapted from Ref. (32) (A), and tissue distribution of the expression of eel Kiss1 (B) and Kiss2 (C) mRNAs. Olfactory bulb (OB), telencephalon (Tel), diencephalon (Di), mesencephalon (Mes), cerebellum (Cb), medulla oblongata (MO), pituitary (Pit), eye, liver, kidney, spleen, muscle, adipose tissue (Fat), and ovary were dissected from female silver eels. The relative expression of each Kiss mRNA was normalized to actin mRNA. Each bar represents mean \pm SEM from eight individual samples.

pituitary cells in primary culture; with gnrh-r1a and gnrh-r1b expressions at the limit of detection, primer dimer peaks (melting curve) were obtained. An inhibitory effect of all four synthesized eel Kiss peptides was observed on the expression of gnrh-r2. This inhibitory effect was dose-dependent, the highest inhibition being observed at $10^{-7} \mathrm{M}[\times 0.35$ for $\mathrm{Kp} 1(10), P<0.001 ; \times 0.34$ for Kp2(10), $P<0.001 ; \times 0.33$ for Kp1(15), $P<0.001$; and $\times 0.44$ for Kp2(12), $P<0.001$ ] (Figure 4C).

\section{DISCUSSION}

\section{Eel Kisspeptins}

In order to assess the predicted Kiss 1 and Kiss 2 sequences and further investigate the gene exon-intron structures, we performed specific RACE PCR on Kiss 1 and Kiss 2 transcripts. The sequencing of the RACE PCR products and the comparison of their sequences to the European eel genome provided a partial Kiss 1 mRNA encompassing, at least, two exons and a complete Kiss2 mRNA made of two exons. This structure exhibiting two exons is typical of the conserved structure of Kiss genes (34).

Once translated, both Kiss 1 and Kiss 2 transcripts encoded two proteins presenting the characteristics of the kisspeptin precursors. Among those hallmarks, Kiss1 and Kiss2 precursors presented the conserved kisspeptin-10 sequences, i.e., YNWNSFGLRY for Kiss1 and FNRNPFGLRF for Kiss2. Moreover, Kp1(10) and $\mathrm{Kp} 2(10)$ were followed at their C-terminal extremity by a cleavage and $\alpha$-amidation signature, i.e., GK and GKR motifs, respectively. For many neuropeptides, $\alpha$-amidation is essential for biological activity $(35,36)$. Both eel kisspeptin-10 sequences were encoded by the second exon of each gene transcript in accordance with what has been observed in other species (34).

The eel Kp1(10) sequence was identical to the rat Kp1(10) but, to our knowledge, the only teleost sequence possessing a tryptophan (W) at its third position; other teleosts showed a leucine (L) except chub mackerel with a phenylalanine (F). The eel Kp2(10) sequence was rather unique due to the presence of an arginine (R) at its third position. The occurrence of an arginine at this position has only been reported so far in the Kp1(10) of the musk shrew (Suncus murinus) (37). Kp2(10) sequences appeared more conserved among vertebrates than $\mathrm{Kp} 1(10)$ ones, differing by one amino acid versus three (Figure S1 in Supplementary Material).

Although kisspeptin-10 is considered as the minimal sequence capable of activating KissR $(6,7)$, in silico analysis did not provide any evidence for the existence of mature Kp1(10) or Kp2(10) in any vertebrate including the European eel. Using the NeuroPred tool, we were able to predict the $\mathrm{N}$-terminal cleavage site for each kisspeptin precursor. The predictions of these $\mathrm{N}$-terminal cleavage sites in addition to the $\mathrm{C}$-terminal $\alpha$-amidation motifs have delineated potential mature peptides that could be directly cleaved from Kiss 1 and Kiss 2 precursors. Thus, the two likely mature peptides in the European eel were Kp1(15) and Kp2(12). In addition, two potentially longer mature peptides could be predicted: a 31-aa mature peptide for Kiss 1 and a 51-aa mature peptide for Kiss 2 .

The presence of cleavage sites delineating a mature Kp1(15) appears to be conserved among teleosts (Figure S1 in Supplementary Material), except in goldfish Carassius auratus (38) and in chub mackerel Scomber japonicus (39) in which a Kp1(16) is predicted. In contrast, the presence of a glutamic acid (E) at the first position of the eel mature $\mathrm{Kp} 1(15)$ seems to be a unique feature among teleosts. Interestingly, the presence of an $\mathrm{E}$ residue at the first position of a mature $\mathrm{Kp} 1$ is observed in $\mathrm{Kp} 1(16)$ in the sarcopterygians, including mammals and the coelacanth (Latimeria chalumnae), and a non-teleost representative of actinopterygians, a holostean, the spotted gar (Lepisosteus oculatus) (23). This feature could thus represent a common characteristic of sarcopterygians and actinopterygians, which has been conserved in the eel and lost in some other teleosts.

The presence of a basic cleavage site leading to a mature Kp2(12) seems to be also conserved among teleosts such as in the European eel (Figure S1 in Supplementary Material). One 


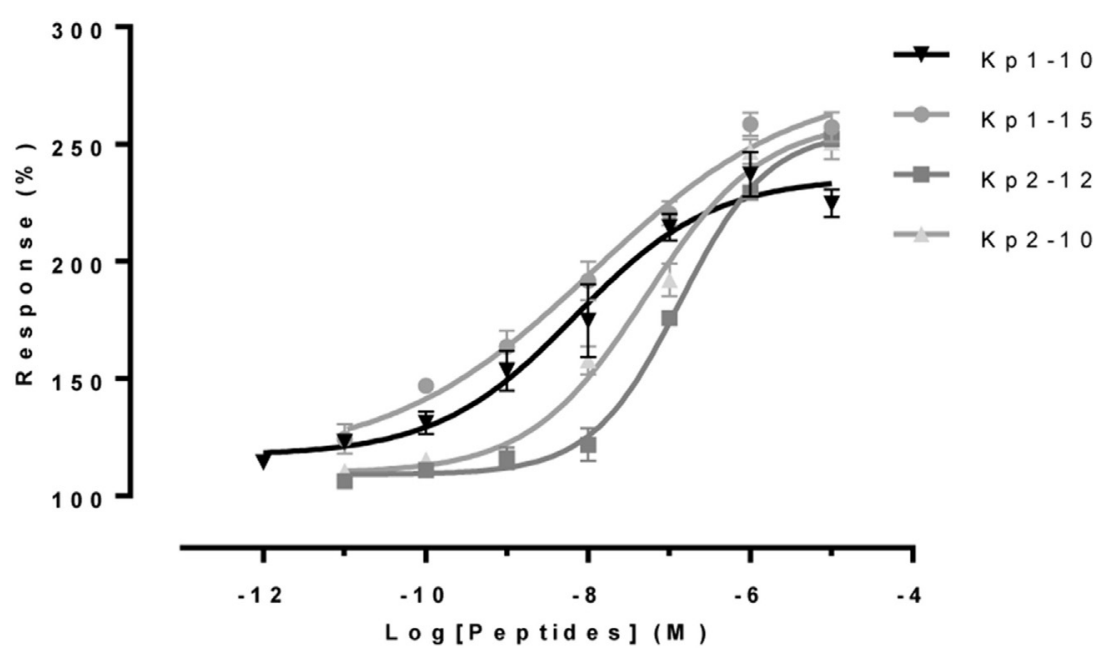

FIGURE 3 | Functional assays of eel Kiss peptides. Levels of [Ca $\left.{ }^{2+}\right]_{i}$ in $\mathrm{CHO}-\mathrm{K} 1$ cells transfected with rat KissR-1 and stimulated with different doses of eel Kp1(10), $\mathrm{Kp} 2(10), \mathrm{Kp} 1(15)$, and Kp2(12) were assessed by using FlexStation technology. After subtraction of mean fluorescence background from control wells without Fluo-4 acetoxymethyl ester, baseline was normalized to 100\%, and fluorescence peak values were determined for each concentration of peptide. Values represent mean \pm SEM from two independent experiments, and average dose-response curves are shown.

exception is observed in salmonids (masu salmon and kokanee salmon, Oncorhynchus nerka) in which the mature endogenous Kiss2 peptide is a 13 -aa sequence (20). The existence of a mature Kp2(12) has been proven in Xenopus (21) and in the red-eared slider turtle (20).

\section{Brain Kiss1 and Kiss2 Expression in the European Eel}

Both eel Kiss 1 and Kiss 2 mRNAs were mainly expressed in the brain, as shown by specific qPCR, Kiss 1 being more abundant in the mesencephalon and Kiss 2 in the diencephalon. Their expressions were also observed in other parts of the central nervous system (i.e., in the telencephalon and cerebellum for Kiss 1 and in the medulla oblongata for Kiss2), although at lower levels. These distributions, which were obtained in the present study, in females at silver stage may differ in males or in females at a different stage.

In other teleosts presenting two Kiss genes, both Kiss 1 and Kiss 2 mRNAs are also expressed in the central nervous system [RT-PCR and qPCR, zebrafish (40-42); RT-PCR, goldfish (43); RT-PCR, sea bass (Dicentrarchus labrax), medaka (Oryzias latipes) (42); RT-PCR and qPCR, chub mackerel (44); qPCR, rohu, Labeo rohita (45); qPCR, Catla catla $(46,47)$; qPCR, pejerrey, Odontesthes bonariensis (48)], suggesting that kisspeptins exert important functions in the teleost brain. Anatomical studies, using ISH and laser-capture microdissection coupled with qPCR, have demonstrated that each transcript is located in different brain nuclei: Kiss $1 \mathrm{mRNA}$ is observed in the ventral habenula, while Kiss 2 mRNA is found in the preoptic region and in the hypothalamus [for review see Ref. (49); European sea bass (50)]. Nevertheless, in striped bass Morone saxatilis (51) and in chub mackerel (39), no Kiss1 expression was reported in the habenular nucleus. In zebrafish, generation of specific antibodies for each kisspeptin type made it possible to evidence that only
Kiss2 neurons send projections to GnRH neurons and pituitary, suggesting a prominent involvement of Kiss2 rather than Kiss1 in the regulation of the gonadotropic activity of this species (52). This is probably also the case in the eel, as Kiss 2 is more actively expressed than Kiss 1 in the diencephalon, which is the main neuroendocrine region of the brain.

In a previous study, we showed the expression of the three eel Kiss receptors in the brain (19). These receptors are differentially expressed in various brain regions. KissR-1 mRNAs is widely expressed in all parts of the eel brain. This receptor is the unique receptor present in placental (eutherian) mammals; the European eel is the only extant teleost shown so far to possess KissR-1, which seems to have been lost in other teleosts $(19,23,24)$. Eel KissR-2 mRNAs is mainly expressed in the telencephalon and the di-/mesencephalon, while KissR-3 expression is primarily observed in the di-/mesencephalon. These data suggest potential multiple actions of kisspeptins in the eel brain that need further investigations.

\section{Pituitary Kiss1 and Kiss2 Expression in the European Eel}

Both Kiss1 and Kiss2 transcripts were expressed in the eel pituitary. In other teleost species possessing two kisspeptin genes, different observations have been reported. Only Kiss 2 expression is detected in zebrafish (52) and pejerrey (48) pituitaries, while only Kiss 1 is expressed in the chub mackerel pituitary (44). In the medaka, none of the two kisspeptin genes is expressed in the pituitary (53), while in the sea bass, both genes are expressed (54), as in the eel.

We previously showed that KissR-1 and KissR-2 are the two receptors expressed in the eel pituitary (19). These data suggest that, in the eel, the pituitary could be a target for the neuroendocrine action of both cerebral and locally produced pituitary 

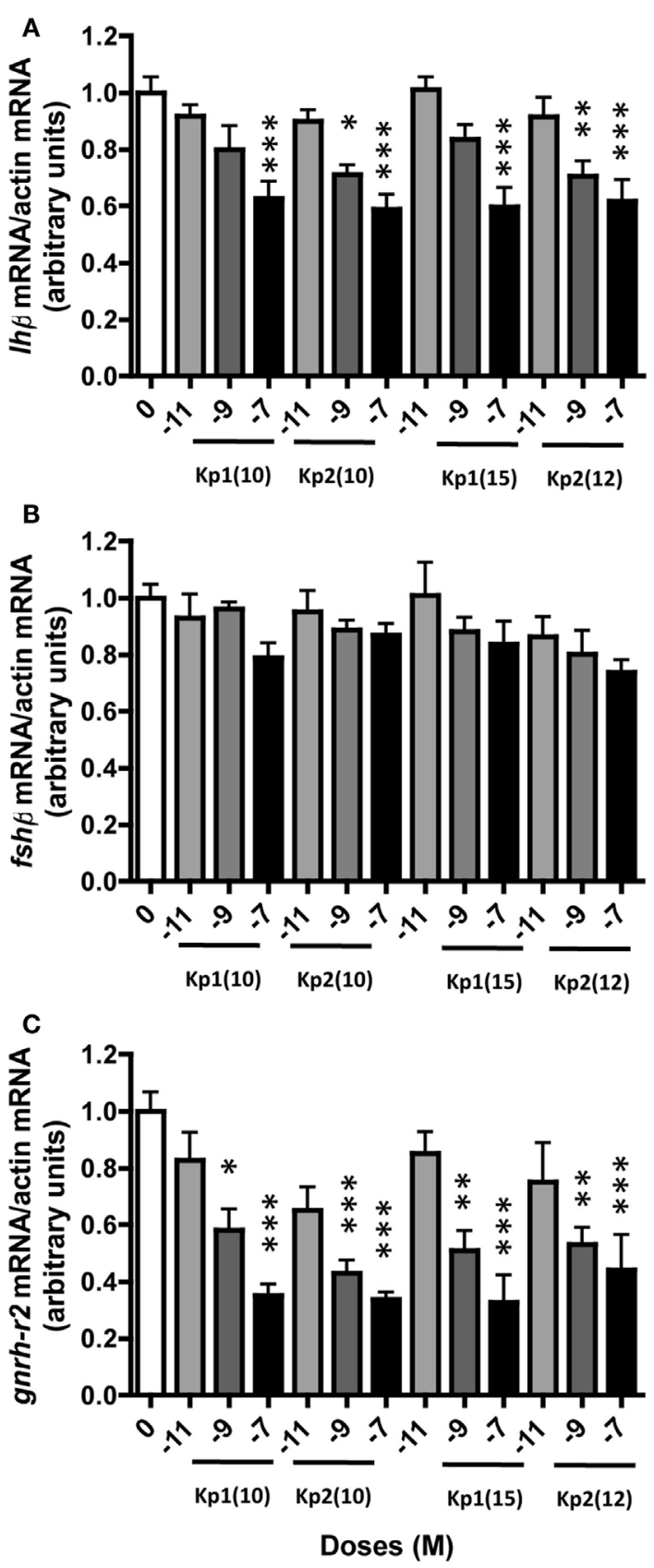

FIGURE 4 | Dose-dependent effect of eel Kiss peptides on pituitary Ih $\beta$ (A), $f \operatorname{sh} \beta$ (B), and gnrh-r2 (C) expression by eel pituitary cells in primary culture. Pituitary cells were treated with various concentrations $\left(10^{-11}, 10^{-9}\right.$, and $10^{-7} \mathrm{M}$ ) of eel Kp1(10), Kp2(10), Kp1(15), and Kp2(12) for 10 days. Pituitary mRNA levels were quantified by quantitative real-time PCR. Data were normalized against $\beta$-actin. This figure displays the results of a representative experiment. Each point represents mean \pm SEM from five-well replicates. ${ }^{\star} P<0.05,{ }^{\star \star} P<0.01$, and ${ }^{\star \star \star} P<0.001$ versus controls, ANOVA.

kisspeptins. Similarly, pituitary expression of Kiss and KissR mRNA, as well as the presence of their respective proteins, has been observed in mammals and amphibians [human $(6,7)$; rat (55-57); ovine (58); and amphibians $(21,59)]$. The occurrence of kisspeptin and its receptor in the pituitary supports the notion that the peptide may exert paracrine and/or autocrine actions in this tissue.

\section{Peripheral Kiss1 and Kiss2 Expression in the European Eel}

In the eel, Kiss 1 and Kiss 2 were weakly expressed in the testis (data not shown) and not in the ovary at the silver stage (prepubertal blockade), which cannot predict a higher expression at a more advanced sexual stage. In other teleosts possessing two kisspeptin genes, different situations have been reported. In some species, both kisspeptins are detected in the gonads [medaka and zebrafish (42, 53); sea bass (60); rohu (45); and Catla catla $(46,47)]$. In contrast, in the chub mackerel, Kiss 1 is expressed in the gonads of both sexes, while Kiss 2 expression is not detected (44), whereas in the pejerrey, expression of both genes is very low in the gonads (48). We previously showed a strong expression of KissR-1 in both the ovary and testis of the European eel (19), which supports a potential endocrine action of Kiss 1 and/or Kiss2 on European eel gonads.

In other peripheral organs, which do not belong to the brainpituitary-gonad axis (muscle, liver, fat, kidney, intestine, spleen, and eye), eel Kiss 1 and Kiss2 expression levels were under the detection limit except in the eye, where Kiss 1 mRNA, but not Kiss2, was clearly expressed. We previously showed the expression of KissR-1 in the eye, suggesting the potential involvement of the kisspeptin system in the local regulation of visual functions. Kiss 1 and Kiss 2 expression also occurs in the eye of other teleost species [zebrafish and medaka (42); rohu (45); and pejerrey (48)]. Kisspeptin receptor mRNAs are also observed in the eye of zebrafish [KissR-3 only (61)] and pejerrey [KissR-2 and KissR-3 (48)]. Interestingly, in the medaka, eye development is interrupted after zygotic knockdown of Kiss1 (62), implying a possible function of the kisspeptin system during retina ontogenesis. Few data are available in other vertebrates. In Xenopus, expression of Kiss-1a and Kiss-1b is observed in the eye, while none of the three kisspeptin receptors and neither Kiss-2 are expressed in this organ (59). In mammals, one study supports a role of kisspeptin as metastasis suppressor gene in the eye, as the expression of both Kiss 1 and its receptor is detected in human uveal melanoma cell lines and correlates with survival rate (63).

\section{Functional Properties of Eel Kiss Peptides}

We demonstrated that all four synthesized eel Kiss peptides were able to bind kisspeptin receptor in heterologous system (CHO-K1 cells stably transfected with rat KissR-1), inducing a rise in intracellular calcium. Eel Kp1(15) exhibited about the same potency to activate rat KissR-1 than eel Kp1(10), which is identical to rat Kp1(10). Interestingly, eel Kiss2-derived peptides were also able to activate rat KissR-1, as zebrafish (59) and sea bass (60) peptides did with human KissR-1.

Zebrafish Kiss peptides are also highly efficient for activating mammalian (human) KissR-1 in COS-7 cells [zebrafish Kp1(10) (41)] and in CV-1 cells [zebrafish Kp1(15), Kp2(10), and Kp2(12) (59)]. Similarly, in CHO cells, sea bass Kiss peptides [sea bass Kp1(10), Kp2(10), Kp1(15), and Kp2(12)] can efficiently activate 
human KissR-1, while, in the case of mouse KissR-1, sea bass $\mathrm{Kp} 2(10)$ is not able to induce any activation (60).

Teleost models, other than eel, possess only two receptors, homologous to eel KissR-2 and eel KissR-3, respectively, as they have lost their KissR-1 paralog, homologous to eel and human KissR-1 (19). For clarity, the nomenclature of Pasquier et al $(19,24)$ for KissR will be used in the following paragraphs. In teleost models with two receptors, various studies have shown differential affinities of Kiss peptides toward homologous receptors. In zebrafish [CV-1 cells (59)] and sea bass [CHO cells (60)], Kp2(12) exhibits higher potency for activating KissR-3, while Kp1(15) exhibits a preference for KissR-2. These data are in agreement with the neuroanatomical distribution of Kiss and KissR-expressing neurons in these two species [zebrafish (52); sea bass $(50,64)]$. However, contradictory results have been obtained by other authors in zebrafish, KissR-2 being activated by both $\mathrm{Kp} 1(10)$ and Kp2(10), while KissR-3 is preferentially activated by Kp1(10) [COS-7, CHO-K1, and HEK293 cells (61)]. In striped bass, Kp1(15) and Kp2(12) activate KissR-3 with the same potency, while KissR-2 is more efficiently activated by Kp2(12) [COS-7 cells (65)]. In the chub mackerel, the predicted mature peptide $\mathrm{Kp} 1(16)$ is more active than the shorter Kp1(15) on KissR-3 (39).

Furthermore, in these homologous receptor and peptide systems, distinct intracellular signal transduction pathways can be activated. KissR-2 and KissR-3 signals can be transduced via both PKA and PKC pathways in zebrafish (41), medaka (66), chub mackerel (67), and sea bass (60). In goldfish, the PKA pathway is activated by Kiss1/KissR-3, while PKC pathway is induced by Kiss2/KissR-2 (43). In the southern Bluefin tuna (Thunnus maccoyii) and in the yellowtail kingfish (Seriola lalandi), KissR-2 (the only receptor present in these species) shows stronger transduction via the PKC than the PKA pathway (68), while in the orange-spotted grouper, Epinephelus coioides, no PKA could be activated (69). In mammals $(6,7)$ and in the bullfrog Rana catesbeiana (21), KissR-1 conveys its signal via the PKC pathway and not the PKA pathway.

As, in the eel, three kisspeptin receptors, KissR-1, KissR-2, and KissR-3, are present, future studies should aim at investigating the potency of homologous kiss peptides to activate each eel KissR and study their signal transduction pathways.

\section{Biological In Vitro Activities of Eel Kiss Peptides on Eel Pituitary Cells}

All four synthetic eel kisspeptins specifically and dosedependently inhibited $\operatorname{lh} \beta$ expression by eel pituitary cells in culture, while they had no effect on $f \operatorname{sh} \beta$ transcripts. These data confirm, using homologous peptides, the specific inhibitory effect of kisspeptin on $\operatorname{lh} \beta$ in the European eel that we previously reported with heterologous Kiss peptides (22).

This paradoxical inhibitory effect contrasts with the general action of kisspeptin as an activator of puberty and reproduction, mostly at the brain level (70), but also directly on the pituitary [for reviews see Ref. $(71,72)$ ]. Our results in the European eel suggest that kisspeptins encoded by both Kiss 1 and Kiss 2 have an inhibitory in vitro effect on $\operatorname{lh} \beta$ expression. Another study, in the striped bass, reported that $\mathrm{Kp} 1(15)$ had an inhibitory effect on th expression, while $\mathrm{Kp} 2(12)$ stimulated LH release (65). In contrast, in other studied teleosts, the action of kisspeptin is generally either stimulatory or absent as in mammals. For instance, in goldfish, homologous $\mathrm{Kp} 1(10)$ and $\mathrm{Kp} 2(10)$ are inactive on LH release by pituitary cells from sexually mature females (43), whereas homologous Kp1(10) increases the release and expression of LH by pituitary cells from mixed sexes at late stages of sexual regression (38). In the sea bass, Kp2(12) induces both $t h$ expression and LH release by pituitary cells obtained from mature males, while Kp1(15) has no effect (73). In (striped and sea) basses, the different actions of Kiss1 and Kiss2 on LH regulation observed in vitro have also been reported in vivo. In the sea bass, $\mathrm{Kp} 2(10)$ is significantly more potent than Kp1(10) in inducing LH secretion after intramuscular (im) injection to both prepubertal and adult fish (42). In the striped bass, im injection of Kp1(15) and Kp2(12) induces plasma LH levels in a stagedependent manner: Kp1(15) has no effect on $\mathrm{LH}$ at pubertal stage, while both peptides could increase LH levels at gonadal recrudescence (51). Our results in the European eel suggest that kisspeptins encoded by both Kiss 1 and Kiss 2 have no in vitro effect on $f s h \beta$ expression. In a few studies, a stimulatory effect of kisspeptins has been reported on FSH. In the striped bass, $\mathrm{Kp} 1(15)$ and $\mathrm{Kp} 2(12)$ stimulate FSH at both the gene transcription and peptide secretion levels (65). In the sea bass, Kp2(12), but not Kp1(15), can induce in vitro FSH release (73). Recently, it was reported that, in amphioxus (Branchiostoma japonicum), injection of amphioxus kisspeptin-like could upregulate the expression of $g p b 5$, a paralog of glycoprotein vertebrate-like $\beta$ subunit (74). Our results on primary cultures of eel pituitary cells indicate that Kiss peptides may act directly at the pituitary cell levels in the eel. The action of Kiss peptides may be exerted directly on pituitary gonadotrophs or via other pituitary cells. We have already shown that heterologous Kiss peptides did not change the expression of $g p \alpha, g h, f \operatorname{sh} \beta$, and $t s h \beta$ in the same in vitro system (22), but indirect action on LH cells may occur via some other factors produced by pituitary cells other than LH cells. Our previous studies revealed that Kiss receptors (KissR-1 and KissR-2) are expressed in the eel pituitary (19). Future in situ hybridization studies would be necessary to decipher whether KissR and which type(s) are expressed by LH cells. Future experiments may also aim at investigating the in vitro effects of specific antagonists for KissR on $l h \beta$ and gnrh- $r 2$ expression. In mammals, including humans, Kiss peptides may act not only via their cognate receptor (Kiss-R = GPR54) but also via other RF-amide receptors that show less specificity such as NPFF receptors 1 and 2 [for instance see Ref. (75)]. This opens further research avenues aiming at characterizing the full complement of RF-amide receptors in the eel.

Besides the inhibitory action on $\operatorname{lh} \beta$ expression of eel kisspeptins, the present study reveals a dose-dependent inhibitory effect on the expression of $g n r h-r 2$ by primary culture of eel pituitary cells. This receptor is the one increased during experimental maturation in both female and male eels (25). To the best of our knowledge, only a single other study investigated the effect of kisspeptin on $\mathrm{GnRH}$ receptor in teleost. In female striped bass at dummy run phase (ovarian development is initiated but not completed), chronic administration in vivo of both Kp1(15) and 
Kp2(12) induces a decrease of pituitary gnrh-r mRNAs (76). In other vertebrates, the few studies available have been mainly performed in mammals and demonstrate a stimulatory or an absence of effect of kisspeptins on the expression of $\mathrm{GnRH}$ receptor. Using the mouse pituitary gonadotroph L $\beta$ T2 cell line, Witham and collaborators (77) have found that kisspeptin treatment cannot activate GnRH receptor promoter, but, in contrast, Mijiddorj et al. (78) have recently demonstrated that kisspeptin increases the expression of $\mathrm{GnRH}$ receptor. While the presence of Kiss/KissR is under question in birds, repeated injections of human Kp1(10) upregulated pituitary expression of type II (but not type I) gnrh-r in the juvenile female Japanese quail (Coturnix japonica) (79). In the anuran amphibian Pelophylax esculentus, Kp10 treatment of testes in culture upregulated the expression of the three gnrh-r before and during the reproductive periods, and this effect was completely abolished/counteracted by the antagonist Kp-234 (80).

Our finding suggests that, in the eel, kisspeptins decreased $\ln \beta$ expression directly at the pituitary level and also decreased pituitary sensitivity to $\mathrm{GnRH}$ by downregulating $\mathrm{GnRH}$ receptor expression, leading to a double inhibitory control. The kisspeptin system may thus contribute to the strong inhibitory control of puberty observed in the European eel. This inhibition in the eel, which contrasts with the stimulatory role of kisspeptin in the

\section{REFERENCES}

1. Rousseau K, Lafont AG, Pasquier J, Maugars G, Jolly C, Sébert ME, et al. Advances in eel reproductive physiology and endocrinology. In: Trischitta F, Takei Y, Sébert P, editors. Eel Physiology. Science Publishers (2013). p. 1-43.

2. Stone R. Freshwater eels are slip-sliding away. Science (2003) 302:221-2. doi:10.1126/science.302.5643.221

3. De Pinna MCC. Teleostean monophyly. In: Stiassny MLJ, Parenti LR, Johnson GD, editors. Interrelationships of Fishes. New York: Academic Press (1996). p. 147-62.

4. Lee J, Miele ME, Hicks DJ, Karen K, Trent J, Weissman B, et al. KiSS-1, a novel human malignant melanoma. Cancer (1996) 88:1731-7.

5. Lee DK, Nguyen T, O'Neill GP, Cheng R, Liu Y, Howard AD, et al. Discovery of a receptor related to the galanin receptors. FEBS Lett (1999) 446:103-7. doi:10.1016/S0014-5793(99)00009-5

6. Kotani M, Detheux M, Vandenbogaerde A, Communi D, Vanderwinden JM, Le Poul E, et al. The metastasis suppressor gene KiSS-1 encodes kisspeptins, the natural ligands of the orphan G protein-coupled receptor GPR54. J Biol Chem (2001) 276:34631-6. doi:10.1074/jbc.M104847200

7. Muir AI, Chamberlain L, Elshourbagy NA, Michalovich D, Moore DJ, Calamari A, et al. AXOR12, a novel human G protein-coupled receptor, activated by the peptide KiSS-1. J Biol Chem (2001) 276:28969-75. doi:10.1074/ jbc.M102743200

8. Ohtaki T, Shintani Y, Honda S, Matsumoto H, Hori A, Kanehashi K, et al. Metastasis suppressor gene KiSS-1 encodes peptide ligand of a G-proteincoupled receptor. Nature (2001) 411:613-7. doi:10.1038/35079135

9. de Roux N, Genin E, Carel J-C, Matsuda F, Chaussain J-L, Milgrom E. Hypogonadotropic hypogonadism due to loss of function of the KiSS1derived peptide receptor GPR54. Proc Natl Acad Sci U S A (2003) 100:10972-6. doi:10.1073/pnas.1834399100

10. Seminara SB, Messager S, Chatzidaki EE, Thresher RR, Acierno JS Jr, Shagoury JK, et al. The GPR54Gene as a regulator of puberty. N Engl J Med (2003) 349:1614-27. doi:10.1056/NEJMoa035322

11. Funes S, Hedrick JA, Vassileva G, Markowitz L, Abbondanzo S, Golovko A, et al. The KiSS-1 receptor GPR54 is essential for the development of the murine reproductive system. Biochem Biophys Res Commun (2003) 312:1357-63. doi:10.1016/j.bbrc.2003.11.066 reproduction of other vertebrates, reveals evolutionary change in the reproductive role of kisspeptin.

\section{AUTHOR CONTRIBUTIONS}

JP, A-GL, and FD: cloning-qPCR (tissue distribution). JP and KR: primary cultures. BL and JL: synthesis of kiss peptides. CD, AM-H, and JL: binding studies. JP, HV, JL, SD, and KR: designwriting. All authors: final approval.

\section{ACKNOWLEDGMENTS}

We thank Eric Ryckelynck and his team from Nodaiwa (Paris, France) for their kind cooperation. This work was supported by grants from the European Community PRO-EEL No. 245257 to A-GL and SD, from the National Research Agency NEMO No. ANR-08-BLAN-0173 to JP, A-GL, KR, SD, BL, and JL and from FrenchKiSS No. ANR-07-BLAN-0056-04 to JL and HV.

\section{SUPPLEMENTARY MATERIAL}

The Supplementary Material for this article can be found online at http://www.frontiersin.org/articles/10.3389/fendo.2017.00353/ full\#supplementary-material.

12. d'Anglemont de Tassigny X, Fagg LA, Carlton MBL, Colledge WH. Kisspeptin can stimulate gonadotropin-releasing hormone $(\mathrm{GnRH})$ release by a direct action at GnRH nerve terminals. Endocrinology (2008) 149:3926-32. doi:10.1210/en.2007-1487

13. Teles M, Bianco S, VN B, Trarbach E, Kuohung W, Xu S, et al. A GPR54activating mutation in a patient with central precocious puberty. $N$ Engl $J$ Med (2008) 358:709-15. doi:10.1056/NEJMoa073443

14. Silveira LG, Noel SD, Silveira-Neto AP, Abreu AP, Brito VN, Santos MG, et al. Mutations of the KISS1 gene in disorders of puberty. J Clin Endocrinol Metab (2010) 95:2276-80. doi:10.1210/jc.2009-2421

15. García-Galiano D, Pinilla L, Tena-Sempere M. Sex steroids and the control of the Kiss1 system: developmental roles and major regulatory actions. J Neuroendocrinol (2012) 24:22-33. doi:10.1111/j.1365-2826.2011. 02230.x

16. Pinilla L, Aguilar E, Dieguez C, Millar RP, Tena-Sempere M. Kisspeptins and reproduction: physiological roles and regulatory mechanisms. Physiol Rev (2012) 92:1235-316. doi:10.1152/physrev.00037.2010

17. Putteeraj M, Soga T, Ubuka T, Parhar IS. A “timed” kiss is essential for reproduction: lessons from mammalian studies. Front Endocrinol (2016) 7:121. doi:10.3389/fendo.2016.00121

18. Tang H, Liu Y, Luo D, Ogawa S, Yin Y, Li S, et al. The kiss/kissr systems are dispensable for zebrafish reproduction: evidence from gene knockout studies. Endocrinology (2015) 156:589-99. doi:10.1210/en.2014-1204

19. Pasquier J, Lafont A-G, Jeng S-R, Morini M, Dirks R, van den Thillart G, et al. Multiple kisspeptin receptors in early osteichthyans provide new insights into the evolution of this receptor family. PLoS One (2012) 7:e48931. doi:10.1371/ journal.pone.0048931

20. Osugi T, Ohtaki N, Sunakawa Y, Son YL, Ohkubo M, Iigo M, et al. Molecular evolution of Kiss2 genes and peptides in vertebrates. Endocrinology (2013) 154:4270-80. doi:10.1210/en.2012-2267

21. Moon JS, Lee YR, Oh DY, Hwang JI, Lee JY, Kim JI, et al. Molecular cloning of the bullfrog kisspeptin receptor GPR54 with high sensitivity to Xenopus kisspeptin. Peptides (2009) 30:171-9. doi:10.1016/j.peptides.2008.04.015

22. Pasquier J, Lafont AG, Leprince J, Vaudry H, Rousseau K, Dufour S. First evidence for a direct inhibitory effect of kisspeptins on LH expression in the eel, Anguilla anguilla. Gen Comp Endocrinol (2011) 173:216-25. doi:10.1016/j. ygcen.2011.05.019 
23. Pasquier J, Lafont A-G, Tostivint H, Vaudry H, Rousseau K, Dufour S. Comparative evolutionary histories of kisspeptins and kisspeptin receptors in vertebrates reveal both parallel and divergent features. Front Endocrinol (2012) 3:173. doi:10.3389/fendo.2012.00173

24. Pasquier J, Kamech N, Lafont AG, Vaudry H, Rousseau K, Dufour S. Molecular evolution of GPCRs: kisspeptin/kisspeptin receptors. J Mol Endocrinol (2014) 52:T101-17. doi:10.1530/JME-13-0224

25. Peñaranda DS, Mazzeo I, Hildahl J, Gallego V, Nourizadeh-Lillabadi R, Pérez L, et al. Molecular characterization of three GnRH receptor paralogs in the European eel, Anguilla anguilla: tissue-distribution and changes in transcript abundance during artificially induced sexual development. Mol Cell Endocrinol (2013) 369:1-14. doi:10.1016/j.mce.2013.01.025

26. Henkel CV, Burgerhout E, de Wijze DL, Dirks RP, Minegishi Y, Jansen HJ, et al. Primitive duplicate hox clusters in the European eel's genome. PLoS One (2012) 7:e32231. doi:10.1371/journal.pone.0032231

27. Aroua S, Weltzien F-A, Le Belle N, Dufour S. Development of real-time RT-PCR assays for eel gonadotropins and their application to the comparison of in vivo and in vitro effects of sex steroids. Gen Comp Endocrinol (2007) 153:333-43. doi:10.1016/j.ygcen.2007.02.027

28. Petersen TN, Brunak S, von Heijne G, Nielsen H. SignalP 4.0: discriminating signal peptides from transmembrane regions. Nat Methods (2011) 8:785-6. doi: $10.1038 /$ nmeth. 1701

29. Southey BR, Amare A, Zimmerman TA, Rodriguez-Zas SL, Sweedler JV. NeuroPred: a tool to predict cleavage sites in neuropeptide precursors and provide the masses of the resulting peptides. Nucleic Acids Res (2006) 34:267-72. doi:10.1093/nar/gkl161

30. Gutiérrez-Pascual E, Leprince J, Martínez-Fuentes AJ, Ségalas-Milazzo I, Pineda R, Roa J, et al. In vivo and in vitro structure-activity relationships and structural conformation of kisspeptin-10-related peptides. Mol Pharmacol (2009) 76:58-67. doi:10.1124/mol.108.053751

31. Dubessy C, Cartier D, Lectez B, Bucharles C, Chartrel N, Montero-Hadjadje M, et al. Characterization of urotensin II, distribution of urotensin II, urotensin II-related peptide and UT receptor mRNAs in mouse: evidence of urotensin II at the neuromuscular junction. J Neurochem (2008) 107:361-74. doi:10.1111/ j.1471-4159.2008.05624.x

32. Weltzien F-A, Pasqualini C, Vernier P, Dufour S. A quantitative real-time RT-PCR assay for European eel tyrosine hydroxylase. Gen Comp Endocrinol (2005) 142:134-42. doi:10.1016/j.ygcen.2004.12.019

33. Montero M, Le Belle N, Vidal B, Dufour S. Primary cultures of dispersed pituitary cells from estradiol-pretreated female silver eels (Anguilla anguilla L.): immunocytochemical characterization of gonadotropic cells and stimulation of gonadotropin release. Gen Comp Endocrinol (1996) 104:103-15. doi:10.1006/gcen.1996.0146

34. Tena-Sempere M, Felip A, Gómez A, Zanuy S, Carrillo M. Comparative insights of the kisspeptin/kisspeptin receptor system: lessons from nonmammalian vertebrates. Gen Comp Endocrinol (2012) 175:234-43. doi:10.1016/j.ygcen.2011.11.015

35. Eipper BA, Stoffers DA, Mains RE. The biosynthesis of neuropeptides: peptide alpha-amidation. Annu Rev Neurosci (1992) 15:57-85. doi:10.1105/ tpc.008425.response

36. Le Marec O, Neveu C, Lefranc B, Dubessy C, Boutin JA, Do-Régo JC, et al. Structure-activity relationships of a series of analogues of the RFamide-related peptide 26RFa. J Med Chem (2011) 54:4806-14. doi:10.1021/jm200418c

37. Inoue N, Sasagawa K, Ikai K, Sasaki Y, Tomikawa J, Oishi S, et al. Kisspeptin neurons mediate reflex ovulation in the musk shrew (Suncus murinus). Proc Natl Acad Sci U S A (2011) 108:17527-32. doi:10.1073/pnas.1113035108

38. Yang B, Jiang Q, Chan T, Ko WK, Wong AO. Goldfish kisspeptin: molecular cloning, tissue distribution of transcript expression, and stimulatory effects on prolactin, growth hormone and luteinizing hormone secretion and gene expression via direct actions at the pituitary level. Gen Comp Endocrinol (2010) 165:60-71. doi:10.1016/j.ygcen.2009.06.001

39. Ohga H, Adachi H, Kitano H, Yamaguchi A, Matsuyama M. Kiss1 hexadecapeptide directly regulates gonadotropin-releasing hormone 1 in the scombroid fish, chub mackerel. Biol Reprod (2017) 96:376-88. doi:10.1095/ biolreprod.116.142083

40. van Aerle R, Kille P, Lange A, Tyler CR. Evidence for the existence of a functional Kiss1/Kiss1 receptor pathway in fish. Peptides (2008) 29:57-64. doi:10.1016/j.peptides.2007.10.018
41. Biran J, Ben-Dor S, Levavi-Sivan B. Molecular identification and functional characterization of the kisspeptin/kisspeptin receptor system in lower vertebrates. Biol Reprod (2008) 79:776-86. doi:10.1095/biolreprod.107.066266

42. Felip A, Zanuy S, Pineda R, Pinilla L, Carrillo M, Tena-Sempere M, et al. Evidence for two distinct KiSS genes in non-placental vertebrates that encode kisspeptins with different gonadotropin-releasing activities in fish and mammals. Mol Cell Endocrinol (2009) 312:61-71. doi:10.1016/j.mce.2008.11.017

43. Li S, Zhang Y, Liu Y, Huang X, Huang W, Lu D, et al. Structural and functional multiplicity of the kisspeptin/GPR54 system in goldfish (Carassius auratus). J Endocrinol (2009) 201:407-18. doi:10.1677/JOE-09-0016

44. Selvaraj S, Kitano H, Fujinaga Y, Ohga H, Yoneda M, Yamaguchi A, et al. Molecular characterization, tissue distribution, and mRNA expression profiles of two kiss genes in the adult male and female chub mackerel (Scomber japonicus) during different gonadal stages. Gen Comp Endocrinol (2010) 169:28-38. doi:10.1016/j.ygcen.2010.07.011

45. Saha A, Pradhan A, Sengupta S, Nayak M, Samanta M, Sahoo L, et al. Molecular characterization of two kiss genes and their expression in rohu (Labeo rohita) during annual reproductive cycle. Comp Biochem Physiol B Biochem Mol Biol (2016) 191:135-45. doi:10.1016/j.cbpb.2015.10.008

46. Rather MA, Bhat IA, Gireesh-Babu P, Chaudhari A, Sundaray JK, Sharma R. Molecular characterization of kisspeptin gene and effect of nano-encapsulted kisspeptin-10 on reproductive maturation in Catla catla. Domest Anim Endocrinol (2016) 56:36-47. doi:10.1016/j.domaniend.2016.01.005

47. Rather M, Bhat IA, Rathor PK, Gireesh-Babu P, Chaudhari A, Kumar SJ, et al. In silico analysis and expression studies of kisspeptin gene in C. catla. J Biomol Struct Dyn (2017) 35(11):2485-96. doi:10.1080/07391102.2016.1222970

48. Tovar Bohórquez MO, Mechaly AS, Hughes LC, Campanella D, Ortí G, Canosa LF, et al. Kisspeptin system in pejerrey fish (Odontesthes bonariensis). Characterization and gene expression pattern during early developmental stages. Comp Biochem Physiol A Mol Integr Physiol (2017) 204:146-56. doi:10.1016/j.cbpa.2016.11.014

49. Ogawa S, Parhar IS. Anatomy of the kisspeptin systems in teleosts. Gen Comp Endocrinol (2013) 181:169-74. doi:10.1016/j.ygcen.2012.08.023

50. Escobar S, Felip A, Gueguen MM, Zanuy S, Carrillo M, Kah O, et al. Expression of kisspeptins in the brain and pituitary of the European sea bass (Dicentrarchus labrax). JComp Neurol (2013) 521:933-48. doi:10.1002/cne.23211

51. Zmora N, Stubblefield J, Zulperi Z, Biran J, Levavi-Sivan B, Muñoz-Cueto JA, et al. Differential and gonad stage-dependent roles of kisspeptin1 and kisspeptin 2 in reproduction in the modern teleosts, morone species. Biol Reprod (2012) 86:177. doi:10.1095/biolreprod.111.097667

52. Servili A, Le Page Y, Leprince J, Caraty A, Escobar S, Parhar IS, et al. Organization of two independent kisspeptin systems derived from evolutionary-ancient kiss genes in the brain of zebrafish. Endocrinology (2011) 152:1527-40. doi:10.1210/en.2010-0948

53. Kitahashi T, Ogawa S, Parhar IS. Cloning and expression of kiss 2 in the zebrafish and medaka. Endocrinology (2009) 150:821-31. doi:10.1210/en.2008-0940

54. Alvarado MV, Carrillo M, Felip A. Expression of kisspeptins and their receptors, gnrh-1/gnrhr-II-1a and gonadotropin genes in the brain of adult male and female European sea bass during different gonadal stages. Gen Comp Endocrinol (2013) 187:104-16. doi:10.1016/j.ygcen.2013.03.030

55. Kinoshita M, Tsukamura H, Adachi S, Matsui H, Uenoyama Y, Iwata K, et al. Involvement of central metastin in the regulation of preovulatory luteinizing hormone surge and estrous cyclicity in female rats. Endocrinology (2005) 146:4431-6. doi:10.1210/en.2005-0195

56. Gutiérrez-Pascual E, Martínez-Fuentes AJ, Pinilla L, Tena-Sempere $M$, Malagón MM, Castaño JP. Direct pituitary effects of kisspeptin: activation of gonadotrophs and somatotrophs and stimulation of luteinising hormone and growth hormone secretion. J Neuroendocrinol (2007) 19:521-30. doi:10.1111/ j.1365-2826.2007.01558.x

57. Richard N, Galmiche G, Corvaisier S, Caraty A, Kottler ML. KiSS-1 and GPR54 genes are co-expressed in rat gonadotrophs and differentially regulated in vivo by oestradiol and gonadotrophin-releasing hormone. JNeuroendocrinol (2008) 20:381-93. doi:10.1111/j.1365-2826.2008.01653.x

58. Smith JT, Rao A, Pereira A, Caraty A, Millar RP, Clarke IJ. Kisspeptin is present in ovine hypophysial portal blood but does not increase during the preovulatory luteinizing hormone surge: evidence that gonadotropes are not direct targets of kisspeptin in vivo. Endocrinology (2008) 149:1951-9. doi:10.1210/ en.2007-1425 
59. Lee YR, Tsunekawa K, Moon MJ, Um HN, Hwang J-I, Osugi T, et al. Molecular evolution of multiple forms of kisspeptins and GPR54 receptors in vertebrates. Endocrinology (2009) 150:2837-46. doi:10.1210/en.20081679

60. Felip A, Espigares F, Zanuy S, Gómez A. Differential activation of kiss receptors by Kiss 1 and Kiss2 peptides in the sea bass. Reproduction (2015) 150:227-43. doi:10.1530/REP-15-0204

61. Onuma TA, Duan C. Duplicated Kiss1 receptor genes in zebrafish: distinct gene expression patterns, different ligand selectivity, and a novel nuclear isoform with transactivating activity. FASEB J (2012) 26:2941-50. doi:10.1096/ fj.11-201095

62. Hodne K, Weltzien FA, Oka Y, Okubo K. Expression and putative function of kisspeptins and their receptors during early development in medaka. Endocrinology (2013) 154:3437-46. doi:10.1210/en.2013-1065

63. Martins C, Fernandes B, Antecka E, Di Cesare S, Mansure J, Marshall J-C, et al. Expression of the metastasis suppressor gene KISS1 in uveal melanoma. Eye (2008) 22:707-11. doi:10.1038/sj.eye.6703090

64. Escobar S, Servili A, Espigares F, Gueguen MM, Brocal I, Felip A, et al. Expression of kisspeptins and kiss receptors suggests a large range of functions for kisspeptin systems in the brain of the European sea bass. PLoS One (2013) 8:e70177. doi:10.1371/journal.pone.0070177

65. Zmora N, Stubblefield JD, Wong T-T, Levavi-Sivan B, Millar RP, Zohar Y. Kisspeptin antagonists reveal kisspeptin 1 and kisspeptin 2 differential regulation of reproduction in the teleost, Morone saxatilis. Biol Reprod (2015) 93:76. doi:10.1095/biolreprod.115.131870

66. Kanda S, Akazome Y, Mitani Y, Okubo K, Oka Y. Neuroanatomical evidence that kisspeptin directly regulates isotocin and vasotocin neurons. PLoS One (2013) 8:e62776. doi:10.1371/journal.pone.0062776

67. Ohga H, Fujinaga Y, Selvaraj S, Kitano H, Nyuji M, Yamaguchi A, et al. Identification, characterization, and expression profiles of two subtypes of kisspeptin receptors in a scombroid fish (chub mackerel). Gen Comp Endocrinol (2013) 193:130-40. doi:10.1016/j.ygcen.2013.07.016

68. Nocillado JN, Biran J, Lee YY, Levavi-Sivan B, Mechaly AS, Zohar Y, et al. The Kiss2 receptor (Kiss2r) gene in Southern Bluefin Tuna, Thunnus maccoyii and in Yellowtail Kingfish, Seriola lalandi - functional analysis and isolation of transcript variants. Mol Cell Endocrinol (2012) 362:211-20. doi:10.1016/j. mce.2012.06.024

69. Shi Y, Zhang Y, Li S, Liu Q, Lu D, Liu M, et al. Molecular identification of the Kiss2/Kiss1ra system and its potential function during 17alphamethyltestosterone-induced sex reversal in the orange-spotted grouper, Epinephelus coioides. Biol Reprod (2010) 83:63-74. doi:10.1095/biolreprod. 109.080044

70. Oakley AE, Clifton DK, Steiner RA. Kisspeptin signaling in the brain. Endocr Rev (2009) 30:713-43. doi:10.1210/er.2009-0005

71. Richard N, Corvaisier S, Camacho E, Kottler M-L. KiSS-1 and GPR54 at the pituitary level: overview and recent insights. Peptides (2009) 30:123-9. doi:10.1016/j.peptides.2008.09.015
72. Gahete MD, Vázquez-Borrego MC, Martínez-Fuentes AJ, Tena-Sempere M, Castaño JP, Luque RM. Role of the Kiss1/Kiss1r system in the regulation of pituitary cell function. Mol Cell Endocrinol (2016) 438:100-6. doi:10.1016/j. mce.2016.07.039

73. Espigares F, Zanuy S, Gomez A. Kiss2 as a regulator of Lh and Fsh secretion via paracrine/autocrine signaling in the teleost fish European sea bass (Dicentrarchus labrax). Biol Reprod (2015) 93:114-114. doi:10.1095/ biolreprod.115.131029

74. Wang P, Wang M, Ji G, Yang S, Zhang S, Liu Z. Demonstration of a functional Kiss-Kissr system in amphioxus with implications for origin of neuroendocrine regulation. Endocrinology (2017) 158(5):1461-73. doi:10.1210/en.2016-1848

75. Oishi S, Misu R, Tomita K, Setsuda S, Masuda R, Ohno H, et al. Activation of neuropeptide FF receptors by kisspeptin receptor ligands. ACS Med Chem Lett (2011) 2:53-7. doi:10.1021/ml1002053

76. Zmora N, Stubblefield J, Golan M, Servili A, Levavi-Sivan B, Zohar Y. The medio-basal hypothalamus as a dynamic and plastic reproduction-related kisspeptin-gnrh-pituitary center in fish. Endocrinology (2014) 155:1874-86. doi:10.1210/en.2013-1894

77. Witham EA, Meadows JD, Hoffmann HM, Shojaei S, Coss D, Kauffman AS, et al. Kisspeptin regulates gonadotropin genes via immediate early gene induction in pituitary gonadotropes. Mol Endocrinol (2013) 27:1283-94. doi:10.1210/me.2012-1405

78. Mijiddorj T, Kanasaki H, Sukhbaatar U, Oride A, Hara T, Kyo S. Mutual regulation by $\mathrm{GnRH}$ and kisspeptin of their receptor expression and its impact on the gene expression of gonadotropin subunits. Gen Comp Endocrinol (2017) 246:382-9. doi:10.1016/j.ygcen.2017.01.014

79. Ni Y, Huang Y, Xiao Y, Wu J, Qian F, Grossmann R, et al. Effects of repeated injection of kisspeptin-10 on the initiation of egg-laying in juvenile quail Anim Reprod Sci (2012) 134:203-9. doi:10.1016/j.anireprosci.2012.08.022

80. Chianese R, Ciaramella V, Fasano S, Pierantoni R, Meccariello R. Kisspeptin drives germ cell progression in the anuran amphibian Pelophylax esculentus: a study carried out in ex vivo testes. Gen Comp Endocrinol (2015) 211:81-91. doi:10.1016/j.ygcen.2014.11.008

Conflict of Interest Statement: The authors declare that the research was conducted in the absence of any commercial or financial relationships that could be construed as a potential conflict of interest.

The reviewer JA declared a past coauthorship with several of the authors SD and A-GL to the handling editor.

Copyright (c) 2018 Pasquier, Lafont, Denis, Lefranc, Dubessy, Moreno-Herrera, Vaudry, Leprince, Dufour and Rousseau. This is an open-access article distributed under the terms of the Creative Commons Attribution License (CC BY). The use, distribution or reproduction in other forums is permitted, provided the original author(s) or licensor are credited and that the original publication in this journal is cited, in accordance with accepted academic practice. No use, distribution or reproduction is permitted which does not comply with these terms. 